\title{
Higher thinking and digital literacy: Empowering technology for pre-service mathematics teacher
}

\author{
Wanda Nugroho Yanuarto ${ }^{1}$, Anton Jaelani ${ }^{1}$ \\ ${ }^{1}$ Universitas Muhammadiyah Purwokerto, Indonesia \\ $\llbracket$ wandanugroho86@gmail.com *
}

\author{
Article Information \\ Submitted August 08, 2021 \\ Revised August 31, 2021 \\ Accepted Sept 09, 2021
}

Keywords

Digital Literacy;

Higher Thinking;

Technology.

\begin{abstract}
Teachers play a more significant role as a symbol of teaching success. Teachers who hold a more potential digital literacy in education teach mathematics with patterns and procedures, leading to practical teaching mathematics. Influential digital literacy and higher thinking are not possible when teachers do not use technology to understand the concept of mathematics. Therefore, teachers are required to improve their technical abilities and higher thinking in mathematics learning. This research used a cross-sectional quantitative research. This research uses statistical analysis of the Kaiser Meyer-Oikin Test (KMO) and the Barlett's Test to obtain exploratory factor analysis. Subsequently, the analyzed using confirmatory factor analysis and structural equation model with Analysis of Moment Structure (AMOS). The purpose of this research is to provide an overview of the relationship between higher thinking skills and digital literacy. The review discoveries show that teachers' digital literacy has a more significant impact on the use of technology in the classroom, and teachers' higher thinking in the role of technology will encourage teachers to use more technology in their practical teaching. Teachers need to broaden their perspectives on the ability and quality of mathematics teaching that is more easily changed by changing practical instruction in the classroom. One of the reasons mathematics teachers still apply traditional teachings is the lower thinking and low level of digital literacy. Teachers are not capable of teaching the concept of mathematics with technology to students.
\end{abstract}

\section{INTRODUCTION}

Nowadays, teachers have trouble understanding mathematics concepts for instance calculus theory. However, the probability of doing something creative with technology can help to solve the problem. Therefore, mastery of technological knowledge is essential in building higher thinking. The previous researchers have extensively studied the relationship between higher thinking in mathematics learning and digital literacy (Alghamdi, 2017; Throndsen \& Hatlevik, 2016). It led to the wider information about education perspective in mathematics learning. Alghamdi (2017) stated that innovative new ideas start from the firm higher thinking of mathematics learning in terms of mathematical principles, valid concepts, and theories; only then can teachers produce something new and valuable that is needed in answering mathematics questions. It can be linked that the higher thinking of mathematics has a significant impact on digital literacy. It is supported by Connie's (2020) statement, which stated that a higher review of mathematics involves mathematical skills such as being sensitive to problems, finding solutions, making guesses or hypothesis formulas, experimenting to get mathematical knowledge results and procedures with technology. Besides, mathematics technology applied in the classroom helps in the mastery of concepts and formulas about mathematics (Alghamdi, 2017; Throndsen \& Hatlevik, 2016).

Similar research from Barry (2017) revealed the digital literacy possessed by teachers and their thinking ineffective teaching on the use of technology. The results obtained found that

$\begin{array}{ll}\text { How to cite } & \text { Yanuarto, W. N., \& Jaelani, A. (2021). Higher thinking and digital literacy: Empowering technology for pre- } \\ & \text { service mathematics teacher. Al-Jabar: Jurnal Pendidikan Matematika, 12(2), 329-342. } \\ \text { E-ISSN } & 2540-7562 \\ \text { Published by } & \text { Mathematics Education Department, UIN Raden Intan Lampung. }\end{array}$


teachers' digital literacy has a more significant impact on the use of technology in the classroom. At the same time, higher thinking plays a more substantial role as a symbol of teaching success. Whereas, this research investigated the correlation between higher thinking and digital literacy. The discoveries showed higher thinking has a significant role in the students' digital literacy. In line with the research results obtained by Mansyur (2018), they said that clear higher thinking is not possible when teachers do not use technology to understand the concepts of mathematics. Therefore, teachers are required to improve digital abilities in teaching.

Subsequently, Siswono et al. (2016) explained that teachers need to broaden their perspectives on the ability and quality of mathematics teaching that is more easily changed by changing practical instruction in the classroom first, as mathematics teachers' thinking in their learning. It has correlated with these discoveries, create teachers' higher thinking learning could impact students' creative thinking. Therefore, one of the reasons mathematics teachers still used traditional education is the low level of digital literacy. Teachers feel they do not have the confidence to teach the concepts of mathematics with technology to students. Therefore, they prefer to teach mathematics with patterns and procedures that they are used to; a similar research comes from Haciomeroglu (2018) that pre-service teachers who hold higher education technology in education will teach mathematics effectively. Therefore, a significant relationship between trust and digital literacy must be recognized. The purpose of this research is to provide an overview of the relationship between higher thinking skills and digital literacy.

\section{METHODS}

This research used a cross-sectional quantitative study. According to Chua (2016), this quantitative method provides a detailed description of the studied problem. The justification for obtaining an overview of the relationship between higher thinking and digital literacy is that a teacher can determine the critical success factors in learning mathematics. In addition, the purpose of this research is to provide an overview of the relationship between higher thinking skills and digital literacy. We took 185 pre-service mathematics teachers at the Universitas Muhammadiyah Purwokerto, Indonesia. This research uses two instruments: 12 items higher thinking questionnaire and 17 items digital literacy questionnaire.

This research uses statistical analysis of the Kaiser Meyer-Oikin Test (KMO) and the Barlett's Test to obtain exploratory factor analysis. The validity of the research instrument construct was determined by carrying out a factor analysis on the collected data rather than a pilot study. The reviewer estimates the reserves of Tabachnick and Fidell (2014), which receive a coefficient value greater than 0.3. Barlett's Sphericity and Kaiser-Meyer-Oikin Measure of Sampling Adequacy (KMO) test were administered before completing the factor analysis. The significant Barlett's Test of Sphericity $(\mathrm{p}<0.05)$ indicates that the correlation between items is adequate for factor analysis. The KMO test with a value of more than 0.5 indicates that the data does not have multicollinearity problems and the item is suitable for factor analysis.

Subsequently, the analyzed using confirmatory factor analysis and structural equation model with Analysis of Moment Structure (AMOS) (Kline, 2017). The CFA test is carried out to see the factors used in each structure (higher thinking and digital literacy). Factors that have met the equivalence criteria will be continued with the SEM test to see the strength of the relationship between the two constructs. The detailed research methods are displayed in Figure 1 . 
The questionnaires are

12 items of higher

thinking questionnaire

and 17 items of digital

literacy questionnaire

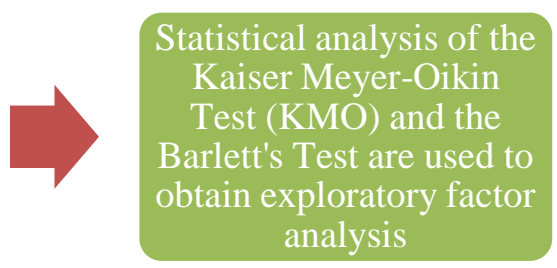

Kaiser Meyer-Oikin

Test (KMO) and the

Barlett's Test are used to analysis
Confirmatory factor analysis and structural

equation model with

Analysis of Moment

Structure (AMOS)

Figure 1. The Research Methods

\section{RESULTS AND DISCUSSION}

The results of this research consist of the reliability of research instruments, namely digital literacy and higher thinking. In addition, the results of the analysis of exploratory factor analysis (EFA), confirmatory factor analysis (CFA), and structural equation model (SEM) are presented. The details of these results are as follows:

\section{Reliability}

This research uses a reliability assessment of Cronbach's Alpha which states that the value of Cronbach's Alpha is above 0.7 (Hair et al., 2014). Therefore, the Cronbach's Alpha value of each instrument can be described in table 1 .

Table 1. The Alpha Cronbach Value

\begin{tabular}{cccc}
\hline No & Instrument & Aspects & Alpha Cronbach \\
\hline 1 & Higher Thinking & Analytical Evaluation (AE) & 0.849 \\
& & Creative Thinking (CR) & 0.839 \\
2 & Digital Literacy & Content Creation (CC) & 0.783 \\
& & Communicative Abilities (CA) & 0.844 \\
& & Critical Understanding (CU) & 0.748 \\
& & Technical Skills (TS) & 0.846 \\
\hline
\end{tabular}

\section{Exploratory Factor Analysis (EFA)}

The results of the EFA analysis found the Kaiser Meyer-Oikin (KMO) value for the items contained in the digital literacy construct, with 17 items showing a value of 0.764 (KMO > 0.5). These results explain that the data collected in the construct can be used to carry out confirmatory factor analysis. In addition, Barlett's test of Sphericity shows a significant value of 0.000 ( $\mathrm{p}<0.05)$, which explains that the digital literacy constructs item is adequate for factor analysis.

On the other way, the total variance explained for the EFA test on the digital literacy construct provides information on four main factors whose value is more significant than one. These four factors accounted for 38.768 changes in the overall variance. Therefore, the total variance explained for the digital literacy construct can be shown in Table 2 .

Table 2. Total Variance Explained for Digital Literacy

\begin{tabular}{ccccccc}
\hline & \multicolumn{3}{c}{ Initial Eigenvalues } & \multicolumn{3}{c}{ Extraction Sums of Squared Loadings } \\
\cline { 2 - 6 } No. & Total & $\begin{array}{c}\text { \% of } \\
\text { variance }\end{array}$ & Cumulative \% & Total & \% of variance & $\begin{array}{c}\text { Cumulative } \\
\%\end{array}$ \\
\hline 1. & 5.811 & 19.370 & 19.370 & 5.811 & 19.370 & 19.370 \\
2. & 2.157 & 7.189 & 26.559 & 2.157 & 7.189 & 26.559 \\
3. & 1.940 & 6.467 & 33.026 & 1.940 & 6.467 & 33.026 \\
4. & 1.723 & 5.742 & 38.768 & 1.723 & 5.742 & 38.768 \\
5. & 1.619 & 5.397 & 44.165 & & & \\
. & & & & & & \\
17 & .268 & 1.574 & 100.000 & &
\end{tabular}

Extraction Method: Principal Component Analysis 
Next, the correlation analysis between each item and the factors performed is shown in the rotated component matrix by extracting the four main elements. The results show that the Content Creation (CC) aspect consists of four items (LD 6, 9, 10, 14, 16), the Communicative Abilities (CA) aspect has three things (LD 4, 5, 15), the Critical Understanding (CU) aspect has three items (LD 1, 2, 8), and the Technical Skills (TS) aspect has three items (LD 11, 13, 17).

Meanwhile, the KMO value obtained from the construct higher thinking also shows 0.842 $(\mathrm{KMO}>0.5)$. This value is adequate for further CFA analysis. Meanwhile, Barlett's Test of Sphericity showed a significant deal of $0.000(\mathrm{p}<0.05)$. These results can also be used for factor analysis. The study of the total variance explained for the higher thinking construct showed two main factors whose eigenvalues were above one. Of the two main factors contributed as many as 31.457 variants overall. The total variance is explained in Table 3.

Table 3. Total Variance Explained for Higher Thinking

\begin{tabular}{ccccccc} 
& \multicolumn{3}{c}{ Initial Eigenvalues } & \multicolumn{3}{c}{ Extraction Sums of Squared Loadings } \\
\cline { 2 - 7 } No. & Total & $\begin{array}{c}\text { \% of } \\
\text { variance }\end{array}$ & Cumulative \% & Total & \% of variance & $\begin{array}{c}\text { Cumulative } \\
\%\end{array}$ \\
\hline 1. & 3.176 & 18.684 & 18.684 & 3.176 & 18.684 & 18.684 \\
2. & 2.171 & 12.773 & 31.457 & 2.171 & 12.773 & 31.457 \\
3. & 1.710 & 10.056 & 41.513 & & & \\
4. & 1.587 & 9.333 & 50.846 & & & \\
5. & 1.342 & 7.893 & 58.739 & & & \\
. & & & & & & \\
12 & .268 & 1.574 & 100.000 & & & \\
\hline \multicolumn{6}{l}{ Extraction Method: Principal Component Analysis }
\end{tabular}

The final EFA analysis for the higher-order construct looks at the items in the two main factors. These results can be shown in the rotated component matrix, which produces the Analytical Evaluation (AE) aspect consisting of six items (LT 1, 2, 3, 4, 11, 12), and the Creative Thinking (CR) aspect, namely six things (LT 5, 6, 7, 8, 9, 10).

\section{Confirmatory Factor Analysis}

The results obtained from CFA on the higher thinking construct resulted in TLI $=0.832$, $\mathrm{CFI}=0.865, \mathrm{RMSEA}=0.126, \mathrm{NFI}=0.830$, and $\mathrm{Chisq} / \mathrm{df}=3.967$. This value is sufficient for the goodness of fit decision for the higher thinking construct. In addition, to see the relationship between aspects of the higher thinking construct, it is found that the relationship between Analytical Evaluation (AE) and Creative Thinking (CR) aspects is 0.820. The value tells that the relationship between the two aspects is very high. The Higher Thinking Model of CFA is presented in Figure 2. 


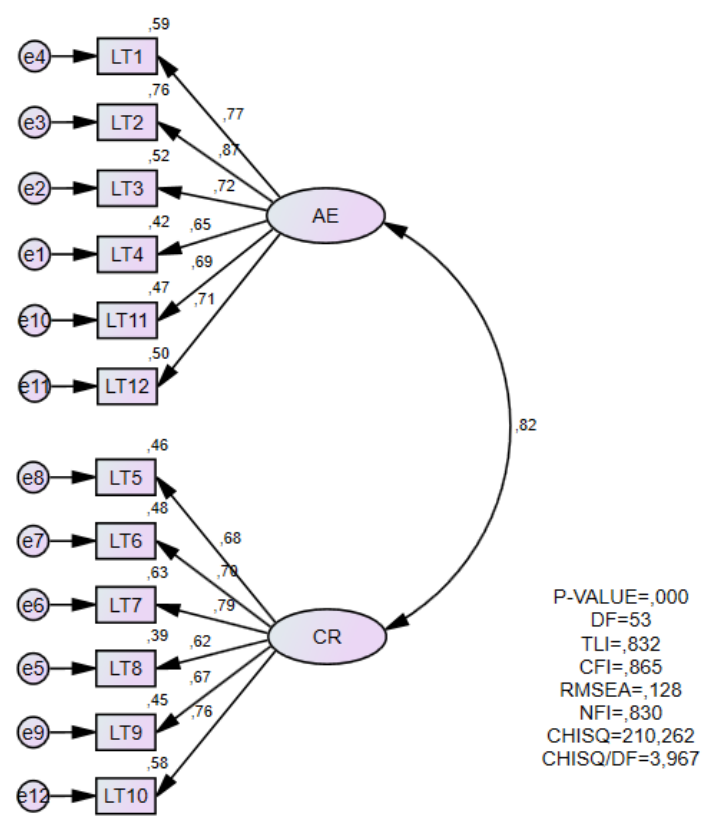

Figure 2. The Higher Thinking Model of CFA

Meanwhile, for the results of the CFA digital literacy construct, TLI $=0.128, \mathrm{CFI}=0.310$, $\mathrm{RMSEA}=0.215, \mathrm{NFI}=0.300$, and Chisq $/ \mathrm{df}=9.401$. From the results of the equivalence index, it is found that the CFA analysis on digital literacy was adequate. Furthermore, the correlation value of the relationship between aspects found that TS and CU are high, the relationship between $\mathrm{CU}$ and CA is high (0.98), the CA correlation with $\mathrm{CC}$ is high, and the relationship between TS and CC is high. Therefore, the correlation value of the relationship between aspects in the digital literacy construct is considered high. The digital literacy model of CFA is shown in Figure 3.

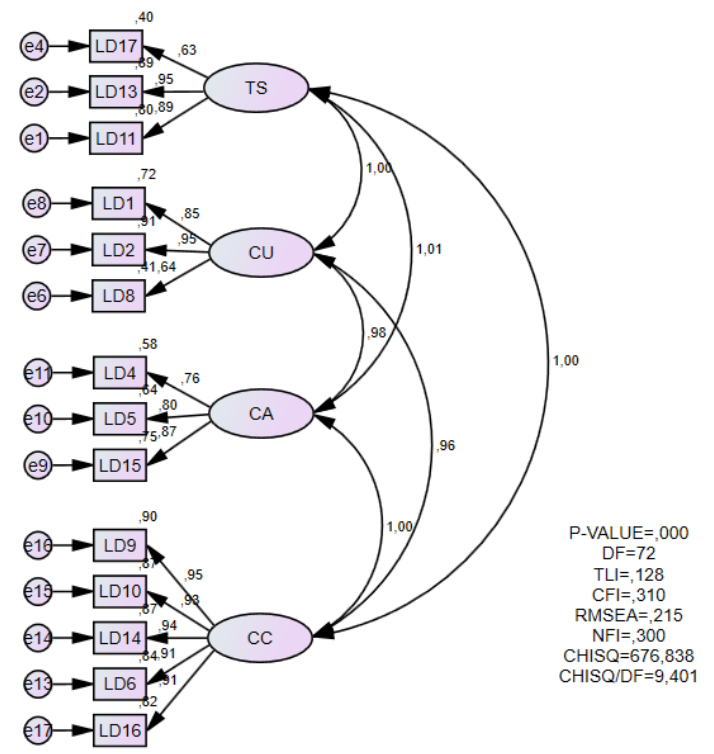

Figure 3. The Digital Literacy Model of CFA

\section{Structural Equation Model (SEM)}

In the SEM analysis, it is found that the correlation value of higher thinking and digital literacy construct is high. In addition, the acquisition of aspect values for each construct is significant. The SEM results on the CC aspect are significant with the acquisition of $=0.90, \mathrm{p}=0.000(\mathrm{p}<$ $0.05)$, TS $(\beta=0.64, p=0.000 ; p<0.05), \mathrm{CA}(\beta=0.61, p=0.000 ; p<0.05)$ and $\mathrm{CU}(\beta=0.57$, 
$\mathrm{p}=0.000 ; \mathrm{p}<0.05)$. Furthermore, for the digital literacy construct, it is found that both aspects are significant, $\operatorname{AE}(\beta=0.91, p=0.000 ; p<0.05)$ and $\mathrm{CR}(\beta=0.76, p=0.000 ; p<0.05)$. Therefore, it can be concluded that the results of the SEM analysis for both constructs (higher thinking and digital literacy) are significant and the correlation between the two is high. The SEM model of relationship between higher thinking and digital literacy is displayed in Figure 4.

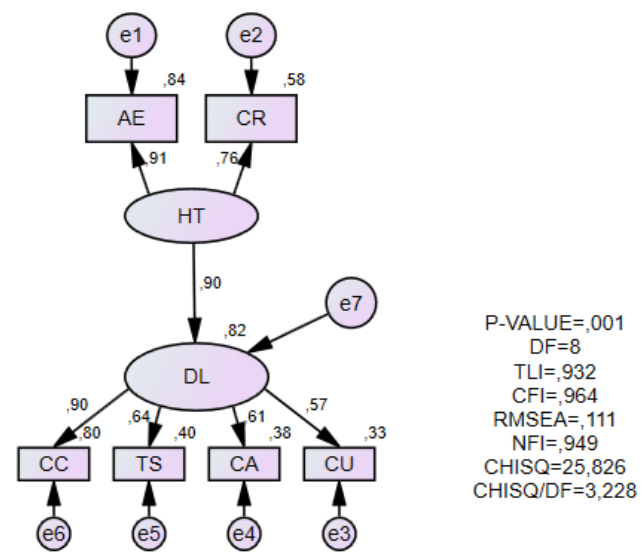

Figure 4. The SEM Model of Higher Thinking and Digital Literacy

\section{Higher Thinking in Mathematics Pre-Service Teachers}

In general, Wulan (2017) explains that teacher higher thinking is a set of solid feelings and attitudes towards teachers about things that can affect teaching interaction. Higher thinking in mathematics learning can be seen as teachers' conscious or unconscious thinking, concepts, meanings, rules, mental images, and inclinations towards the discipline of mathematics. Following Eynde and Corte (2020), higher thinking concepts, views, and priorities contribute to the philosophy of mathematics. In short, this research implied the higher thinking in mathematics deal with ideas, images and are usually related to the mathematical context.

Also, Pagina (2019) revealed three aspects of higher thinking; creative in teaching, critical, and analyzing in education. However, the research of Schlesinger and Wang (2019) describes higher thinking as consisting of two factors; collaboration and communication. Next, mathematics higher thinking contains the process of behavior and mental activity and the reach of conception and image of activities and processes of cognition in general (Eynde \& Corte, 2020). Thus, collaboration in mathematics dominates the actions of teachers in teaching. In comparison, this research discovery stated communication in the role of technology in education can be the core of teachers in action and classroom activities that contain technology in the teaching of mathematics. Therefore, the aspects of higher thinking in this research are creative thinking of mathematics, collaborative teaching of mathematics, and technology communication.

Researches on higher thinking are pictured differently; collaboration as thoughts and actions in mathematics (Muir-Herzig, 2020), creative thinking (Maker, Jo, \& Muammar, 2018), factors of higher thinking (Wulan, 2017), three aspects of higher thinking in education (Eynde \& Corte, 2020). Other researches show that higher thinking held by an individual indicates how mathematics is delivered (Dangel, 2017). Also, Bayat (2018) divides the higher thinking of mathematics into two views; the first is to see mathematics as an absolute power principle (absolutist). More to see mathematics as a problem solution (Novita \& Herman, 2021). The research of Schlesinger and Wang (2019) stated two centers of higher thinking; contemporary- 
orientation constructivism and traditional transmission goal processing orientation. Besides, teachers' higher thinking in the role of technology in the world of education, especially in classroom teaching, becomes an important part (Sang et al., 2018).

This research includes various opinions of experts in the previous explanation; creative thinking of mathematics, collaborative teaching of mathematics, and communication role of technology in education. According to Connie (2020), the creative thinking of mathematics dominates teachers' actions in curriculum implementation. On the other hand, Instefjord (2015) argues that collaborative activities are aspects of mathematics teaching. Whereas, communication role of technology mathematics contains the process of behavior and mental activity in technology, the reach of conception, and image of activities and processes in mathematics learning (Eickelmann \& Vennemann, 2017).

The discoveries of researches conducted by many researchers found that mathematics higher thinking have a strong basis as rules and procedures (Erickson \& Heit, 2013; Fauzi, 2017), high motivation in seeing mathematics as a valuable subject for their daily life (Connie, 2020), and thinking as a solution to problem-solving efforts and mathematics as a problemsolving strategy (Widodo, 2017).

Based on the discoveries of researches that have been conducted related to mathematics technology, the higher thinking in Iran (Durak \& Saritepeci, 2017), similar cases in South Korea (Ni, Zhou, \& Li, 2014) and in China and Thailand (Zhang, 2017). Different researches reveal that many teachers view higher thinking more effectively in Turkey (Uysal \& Dede, 2016). A further Malaysia's research from (Ariffuddin et al., 2019). Finally, the teachers' higher thinking about teaching in Indonesia was suggested by Setiana (2020). Therefore, from the various discoveries of researches described above, higher thinking of mathematics can be divided into teaching activities and technology teaching.

Next, to see the researches discoveries in detail obtained from the survey of Connie (2020), the higher thinking towards mathematics determines the nature of the classroom environment created by the teacher. Next, the lower thought of teachers towards mathematics and the teaching of mathematics is revealed by Erickson and Heit (2013) and Ni et al. (2014). Another research by Instefjord (2015) showed that teachers' higher thinking is more like technology education. Therefore, higher thinking influenced higher technology teaching. Therefore, teachers should broaden their perspectives on the ability and quality of mathematics teaching, which is easier to change by changing the way practical instruction in the classroom into teaching with a better understanding of mathematics content.

\section{Digital Literacy in Mathematics Pre-Service Teachers}

According to Hatlevik and Arnseth (2018), this new literacy practice mediates by the social context and discourse in which the reader is involved. They are a social practice that multimedia texts produced by digital technology are sometimes co-created, and meanings are often cocreated. Digital textbooks, such as the internet, pose challenges for educators. Digital technologies such as weblogs and iPods appear in the social and business world and immerse themselves as icons and cultural needs of a short time (Weippert, Achim, and Kajewski, 2017). The introduction of digital text also happens quickly by educators and researchers to balance or follow new text types and new letter literacy. In contrast, many researchers agree that $21^{\text {st }}$ century literacy instruction should include new literacy, many interpretations of what constitutes new literacy practices (Instefjord, 2015). 
Next, van Borkulo et al. (2019), mathematics software is the most widely used digital in the teaching of mathematics, for example, Geogebra, Autograph, Maple, Mathematica, MathLab, WolframAlpha, Decal graphing calculator, and Microsoft Mathematics. Also, there is mathematics content offered online and allows teachers to use it in the teaching process, or students to download or directly learn from it at their own time and place, for example, Khan Academy, m-Education, Home Study, Youtube, classroom 2.0, and IXL. Furthermore, when a teacher uses digital to use new mathematics teaching strategies, students will eventually learn mathematics using digital, as modeled by flip teaching strategies (Eickelmann \& Vennemann, 2017). Therefore, with the availability of mathematics software, the teaching of mathematics can be designed in different and creative ways, allowing both students and teachers to take advantage of digital teaching that enables it.

Besides, there are also examples of mathematics teaching using digital, as provided by (Aprilisa, 2020). These examples show the strategies, tips, and teaching techniques that teachers can imitate or adapt to their own needs in their teaching. With so many resources available to teachers and students in the learning of mathematics, specific skills are needed for teachers and students to select and adapt resources into their teaching process. These skills will equip teachers and students to carefully choose resources from various perspectives, including the validity of mathematical content or information, breadth, and depth of knowledge. According to Perdana et al. (2019), the future of teaching with digital is the teaching of mathematics as a social activity. The intended social activity is access that will open the door for teachers and students to the rich and abundant educational resources available on the internet. Thus, teaching can take place in and outside the classroom.

In education, digital literacy is increasingly emphasized in general (Hatlevik \& Arnseth, 2018) and especially in mathematics (Connie, 2020) and has been shown to have a positive effect on teaching (Hermans et al., 2018). Despite the increasing emphasis and integration of digital in mathematics, mathematics digital literacy is not explicit. Competency with digital specifically for mathematics will concern educators, curriculum developers, and many more stakeholders in this field. This research also explains the investigation of digital literacy for teachers. By assessing how teachers engage with new and unfamiliar digital to solve mathematical problems and understand the concepts of mathematics, the first features of mathematics digital literacy emerge.

Various literature researches provide an overview of digital literacy. Researches are evaluating that digital literacy does not significantly influence mathematics learning outcomes (Hutchison, 2018). Teachers who are proficient in applying the concept of mathematics in the classroom feel enough to teach mathematics as they usually do. Another reason is that the availability of applicable digital will change the purpose of teaching mathematics itself (Almås \& Krumsvik, 2008).

Some other researches aim at effective teaching of mathematics using some of the existing software. It is in line with technology in today's world of education (Eickelmann \& Vennemann, 2017). Providing teacher assistance in the construction of mathematics in the classroom by scaffolding can also be through digital literacy in the school so that the role of the teacher can be used as a user of teaching both actual mathematics teaching and online mathematics teaching (Instefjord, 2015). Some mathematics lessons that can be applied refer to using digital in the classroom, such as flipped classroom teaching and many more. However, teaching like above is rarely used when teachers do not have digital literacy (Tuggle-haskins, 2020). 


\section{The Higher Thinking and Digital Literacy in Mathematics Pre-Service Teachers}

Higher thinking plays an essential role in the teaching of mathematics. Teaching outcomes have a very high relationship with the attitudes and thinking possessed (Connie, 2020). Over the last 20 years, research on higher thinking has grown exponentially. There are two types of researches that dominate the research of higher thinking. Some researches aim to test the higher thinking of mathematics descriptively, teaching mathematics and the nature of mathematics, and some researches want to see the relationship between higher thinking and teachers' attitudes towards mathematics (Weippert, Achim and Kajewski, 2017) and higher thinking towards digital literacy as a significant issue in the current era of the industrial revolution (Hatlevik \& Arnseth, 2018).

The era of the 4.0 industrial revolution now requires teachers to have digital literacy skills that can be used in the teaching of mathematics. Some opinions say that the role of technology in encouraging teachers to improve instruction in the classroom (Supendi \& Nurjanah, 2019), while others see the role of technology in teaching as harming teachers (Eickelmann \& Vennemann, 2017). Both of the above opinions are based on the higher thinking of the mathematics. Mathematics teachers who have a high level of digital literacy will use technology and have a new color in teaching. It is in line with the research results of Aprilisa (2020) that higher thinking impacts the role of technology. Teachers believe that education that comes from technology requires teachers to be proficient in digital literacy.

Various researches of higher thinking can be due to the factors of teacher teaching experience. For example, the positive relationship between the higher thought of teacher technology in digital literacy is due to the expertise of teachers for five years (Instefjord, 2015). On the other hand, Connie (2020) states that the higher thinking in technology in digital literacy is not due to teaching experience. Thus, the above two researches illustrate that higher thinking in digital literacy is differentiated based on teachers' teaching experience.

Meanwhile, many researchers cite higher thinking of the role of technology in education (Borromeo, Elen, \& Verschaffel, 2019; Doğan, 2012; Montgomery, 2020). Also, many researchers suggest that higher thinking in the role of technology should be given attention. For example, in the research of Borromeo et al. (2019), teachers' higher thinking in the part of technology is used to overcome the problem of attitude towards technology. Doğan (2012) also reveals higher thinking in the role of technology in overcoming problems regarding digital literacy. Besides, in this research, the importance of technology in teaching supports teachers to appreciate digital technology and literacy. Furthermore, teachers understanding of the importance of technology in education can guide teachers to engage in technology to cultivate teachers' digital literacy.

The research of higher thinking in mathematics learning also considers the development of digital literacy. A group of teachers in traditional learning showed lower intentions in using digital literacy (Instefjord, 2015). In contrast to Barry (2017), the constructivist group showed a stronger desire for digital literacy from the beginning, and they maintained this high intention after teaching. However, the discoveries of other researcher say there is no clear line between the technology used by teachers, and even mathematics teachers may choose traditional or constructivism in the use of digital literacy (Connie, 2020). Finally, teachers' beliefs are closely related to teachers' constructivism of teaching beliefs but do not correlate with traditional teaching beliefs. 
Digital literacy has positive benefits in mathematics education, but in reality, sometimes teachers do not use digital at all or use it in a very traditional way (Lim \& Chai, 2008). Teachers' attitudes and thinking about using digital have been critical barriers for teachers to practice and use digital literacy effectively (Instefjord, 2015). Teachers' positive attitude towards digital literacy can be constructed as teachers' higher thinking in technology on the teaching of mathematics (Saleh, 2019), or teachers higher thinking and digital literacy have beneficial in teaching mathematics (Eynde \& Corte, 2020).

In other mathematics education, when teachers showed that digital literacy would enhance the teaching of mathematics, they will consider using technology (Saleh, 2019). However, if teachers believe that to demonstrate an understanding of mathematics, such as computational ability, they will not integrate digital in mathematics education or use it in a very traditional way of transmitting knowledge (Eynde \& Corte, 2020). On the other hand, teachers who have common thinking in technology, then teaching mathematics, tend not to use technology in the classroom and will use the traditional approach (Barry, 2017).

Another research support comes from Eickelmann and Vennemann (2017), who revealed the relationship between the higher thinking that the role of low technology harms the use of technology in the classroom. Teachers with technology problems find it difficult to receive updates on any changes, including technology in the classroom. They also argue that it would worsen if the teacher only used the traditional approach in his teaching sessions. It can be concluded that teachers who do not have mathematics skills will have low digital literacy. Both of these attitudes are obstacles to improving mathematics education. The same thing is explained by Prestridge (2018) that the higher thinking in the role of technology owned by teachers will have a good effect on changes in teaching patterns used by them and more open to digital literacy in the development of teaching using technology. The idea was also felt by Wulan (2017), teachers' academic background and high digital literacy ability is the most important thing for teachers to improve their ability in teaching mathematics with technology.

\section{CONCLUSIONS}

Teachers' higher thinking in the role of technology is used to overcome the problem of attitude towards technology. Such higher thinking, many researchers cite thinking of the part of technology in education. Also, it reveals higher thinking in the role of technology in overcoming problems regarding digital literacy. Besides, the importance of technology in teaching supports teachers in appreciating digital literacy. Furthermore, teachers' understanding of the importance of technology in education can guide teachers to engage in technology to cultivate digital literacy. Besides, the research of constructivist and traditional teaching also considers the development of digital literacy. However, a group of teachers in conventional education showed lower intentions in using digital literacy.

In contrast, the constructivist group showed a stronger desire for digital literacy from the beginning, and they maintained this high intention after teaching. Various other researches state that higher thinking is correlated to digital literacy. However, the discoveries of another research say there is no clear line between the technology used by teachers, and even mathematics teachers may choose traditional or constructivism in the use of digital literacy. Finally, teachers' higher thinking is closely related to teachers' technological learning but does not correlate with conventional education. 
This research provides information about the current status of the stage of higher thinking and digital literacy in mathematics pre-service teachers. The results guide teachers, future researchers, and pre-service teachers to show higher thinking and digital literacy. Furthermore, the structural equation model developed shows a strong relationship between the constructs of higher thinking and digital literacy in mathematics pre-service teachers. However, future researchers can integrate more constructive construct and the wider population to create a wide development model from an education perspective.

\section{AUTHOR CONTRIBUTIONS STATEMENT}

WNY and AJ worked as the main drafter in this research. data collection and instrument design assisted by them.

\section{REFERENCES}

Abel, T., Brazas, J., Jr, D. C., \& Kemp, A. (2018). Characterizing mathematical digital literacy: A preiminary investigation. Journal of Curriculum and Instruction, 4(2), 421-430.

Alghamdi, M. S. (2017). The reality and difficulties of employing ICT in teaching from the perspective of math teachers of middle stage in Riyadh. International Education Studies, 10(12), 109-129.

Almås, A. G., \& Krumsvik, R. (2008). Teaching in technology-rich classrooms: Is there a gap between teachers' intentions and ICT practices? Research in Comparative and International Education, 3(2), 103-121. https://doi.org/10.2304/rcie.2008.3.2.103

Aprilisa, E. (2020). Realizing society 5.0 to face the industrial revolution 4.0 and teacher education curriculum readiness in Indonesia. Proceeding International Conference on Science and Engineering, 3(April), 543-548. https://doi.org/10.14421/icse.v3.559

Ariffuddin, M., Aziz, A., Talib, O., Sulaiman, T., Ariffuddin, M., Aziz, A., \& Talib, O. (2019). The implementation of flipped classroom instructional to enhance academic achievement among form four chemistry students. International Journal of Academic Research, 9(7), 967-980. https://doi.org/10.6007/IJARBSS/v9-i7/6195

Barry, A. (2017). Alleviating math anxiety through the integration of teacher beliefs in senior school. Journal Basic of Education, 3(April), 335-342.

Bayat, S. (2018). Relationship between mathematical thinking, mathematics anxiety and mathematics learning anxiety. Procedia - Social and Behavioral Sciences, 8(5), 537-542. https://doi.org/10.1016/j.sbspro.2010.12.074

Borromeo, E., Elen, J., \& Verschaffel, L. (2019). Relationships between mathematics teachers' acceptance of computer supported-open learning environments and their beliefs: A survey study in italian lower secondary schools. Edulearn 11: 3Rd International Conference on Education and New Learning Technologies, 3(2), 262-271.

Chua, Y. P. (2016). Mastering research methods 2nd edition. New York: Routledge

Connie, C. (2020). Teacher perceived impact of technology on elementary classrooms and teaching. Journal of Digital Learning in Teacher Education, 7(2), 147-173.

Dangel, J. R. (2017). An analysis of research on constructivist teacher education. Journal of Curriculum and Teaching, 17(2), 87-113. 
Doğan, M. (2012). Prospective Turkish primary teachers' views about the use of computers in mathematics education. Journal of Mathematics Teacher Education, 15(4), 329-341. https://doi.org/10.1007/s10857-012-9214-3

Durak, H., \& Saritepeci, M. (2017). Investigating the effect of technology use in education on classroom management within the scope of the FATIH project. Cukurova University Faculty of Education Journal, 46(2), 441-457. https://doi.org/10.14812/cuefd.303511

Eickelmann, B., \& Vennemann, M. (2017). Teachers' attitudes and beliefs regarding ICT in teaching and learning in European countries. European Educational Research Journal, 16(6), 733-761.

Erickson, S., \& Heit, E. (2013). Math and metacognition: Resolving the paradox. 2255-2260.

Eynde, P., \& Corte, E. (2020). Students' higher order thinking and achievement for mathematics learning. Journal of Advanced Research Design, 4(2), 23-37.

Fauzi, M. N. (2017). The comparison of learning model viewed from the students thinking style. 11, 326-330. https://doi.org/10.11591/edulearn.v11i4.6874

Haciomeroglu, G. (2018). Mathematics anxiety and mathmatics beliefs:What is the relationship in elemantary pre-service teacher? Issues in The Undergraduate Mathematics Preparation of School Teachers, 5(February), 1-9.

Hair, J. F., Black, W. C., Babin, B. J., \& Anderson, R. E. (2014). Multivariate data analysis. In Pearson Education Limited.

Hatlevik, O. E., \& Arnseth, H. C. (2018). ICT, teaching and leadership: How do teachers experience the importance of ICT-supportive school leaders? Nordic Journal of Digital Literacy, 2(1), 55-69.

Hermans, R., Tondeur, J., van Braak, J., \& Valcke, M. (2018). The impact of senior school teachers' educational beliefs on the classroom use of computers. Computers and Education, 51(4), 1499-1509. https://doi.org/10.1016/j.compedu.2008.02.001

Hutchison, D. (2018). Technolog in the mathematics classroom. Journal of Emerging Trends in Educational Research and Policy Studies (JETERAPS), 14(June), 1-4.

Instefjord, E. (2015). Appropriation of digital competence in teacher education. Nordic Journal of Digital Literacy, 2015(4), 155-171. https://doi.org/10.2190/EC.38.3.a

Kline, R. B. (2017). Principles and practice of structural equation modeling. Journal Basic of Education, 3(21), 445-458.

Lim, C. P., \& Chai, C. S. (2008). Teachers' pedagogical beliefs and their planning and conduct of computer-mediated classroom lessons. British Journal of Educational Technology, 39(5), 807-828. https://doi.org/10.1111/j.1467-8535.2007.00774.x

Maker, C. J., Jo, S., \& Muammar, O. M. (2018). Development of creativity: The influence of varying levels of implementation of the ICT literacy, a non-traditional teacher beliefs. Learning and Individual Differences, 18(4), 402-417. https://doi.org/10.1016/j.lindif.2008.03.003

Mansyur, M. (2018). Kemampuan literasi ICT guru di SMP Negeri di wilayah Kediri. Jurnal Komunikasi KAREBA, 2(4), 379-385. 
Montgomery, J. (2020). The effects of flipped learning on middle school students' achievement. Journal of Mathematical Sciences \& Mathematics Education, 3(5), 53-68.

Muir-Herzig, R. G. (2020). Technology and its impact in the classroom. Computers and Education, 42(2), 111-131. https://doi.org/10.1016/S0360-1315(03)00067-8

Ni, Y., Zhou, D., Li, X., \& Li, Q. (2014). Relations of instructional tasks to teacher-student discourse in mathematics classrooms of chinese primary schools. Cognition and Instruction, 32(1), 2-43. https://doi.org/10.1080/07370008.2013.857319

Novita, R., \& Herman, T. (2021). Digital technology in learning mathematical literacy, can it helpful? Journal of Physics: Conference Series, 1776(1), 554-563. https://doi.org/10.1088/1742-6596/1776/1/012027

Pagina Thomson. (2019). Higher order thinking skills in mathematics learning. Journal of Advanced Research Design, 15(2), 1. https://doi.org/http://www.jstor.org/stable/1175860

Perdana, R., Yani, R., Jumadi, J., \& Rosana, D. (2019). Assessing students' digital literacy skill in senior high school Yogyakarta. JPI (Jurnal Pendidikan Indonesia), 8(2), 169. https://doi.org/10.23887/jpi-undiksha.v8i2.17168

Prestridge, S. (2018). The beliefs behind the teacher that influences their ICT practices. Computers and Education, 58(1), 449-458. https://doi.org/10.1016/j.compedu.2011.08.028

Saleh, B. (2019). Information and communication technology (ICT) literacy of community in mamminasata region. Jurnal Pekommas, 18(3), 151-160.

Sang, G., Valcke, M., Braak, J. van, \& Tondeur, J. (2018). Teachers' thinking processes and technology integration: Predictors of prospective teaching behaviors with educational technology. Computers and Education, 54(1), 103-112. https://doi.org/10.1016/j.compedu.2009.07.010

Schlesinger, Z., \& Wang, W. I. (2019). Higher order thinking skills and the evolution of learning technology in the 21 century. Journal for Research in Mathematics Education, 4(3), 1528.

Setiana, D. S. (2020). The role of ethnomathematics in welcoming the society 5.0. Journal of Teacher Education, 7(9), 130-134. https://doi.org/10.2991/assehr.k.200827.130

Siswono, T. Y. E., Kohar, A. W., Kurniasari, I., \& Astuti, Y. P. (2016). An investigation of secondary teachers' understanding and belief on mathematical problem solving. Journal of Physics: Conference Series, 693(1). https://doi.org/10.1088/1742-6596/693/1/012015

Supendi, A., \& Nurjanah. (2019). Society 5.0:is it high-order thinking? Global Perspective on 21st Elementary Education, 2(1), 1054-1059.

Tabachnick, B \& Fidell, L. (2014). Using multivariate statistics. In Person Education Limited.

Throndsen, I., \& Hatlevik, O. V. E. E. (2016). Examining gender differences in mathematics anxiety in beliefs perspectives. Norwegian Result from ICILS, 221-240.

Tuggle-haskins, R. (2020). Implementing a flipped classroom in a unit on slope. Education and Human Development Journal, 5(22), 55-69.

Uysal, F., \& Dede, Y. (2016). Mathematics anxiety and beliefs of turkish pre-service elementary 
teachers. EURASIA Journal of Mathematics, Science \& Technology Education, 12(8), 2171-2186. https://doi.org/10.12973/eurasia.2016.1418a

van Borkulo, S. P., Kallia, M., Drijvers, P., Barendsen, E., \& Tolboom, J. (2019). Computational thinking and mathematical thinking: Digital literacy in mathematics curricula. Proceedings of the 14th International Conference on Technology in Mathematics Teaching - ICTMT 14, 6(October), 384-386.

Weippert, Achim and Kajewski, S. (2017). Internet-based Information and communication systems - a case study analysis. Journal Basic of Education, 2(2), 103-116. https://doi.org/10.1016/S0261-5177(02)00005-5

Widodo, S. A. (2017). Guardian student thinking process in resolving issues divergence. Journal of Education and Learning. 11, (4) 431-437. https://doi.org/10.11591/edulearn.v11i4.5639

Wulan T, A. C. (2017). Self assessment for student performance based on higher order thinking skills in physics learning. Journal Basic of Education, 11(3), 445-451. https://doi.org/10.11591/edulearn.v11i4.6456

Zhang, Z. (2017). Teaching ICT to pre-service teachers: experiences and reflections. Learning Landscapes, 8(1), 323-337. 